\title{
Creating capacities for peacebuilding citizenship: history and social studies curricula in Bangladesh, Canada, Colombia, and México
}

\section{Kathy Bickmore, Ahmed Salehin Kaderi \& Ángela Guerra-Sua}

To cite this article: Kathy Bickmore, Ahmed Salehin Kaderi \& Ángela Guerra-Sua (2017)

Creating capacities for peacebuilding citizenship: history and social studies curricula in Bangladesh, Canada, Colombia, and México, Journal of Peace Education, 14:3, 282-309, DOI: 10.1080/17400201.2017.1365698

To link to this article: https://doi.org/10.1080/17400201.2017.1365698

\section{曲 Published online: 17 Aug 2017.}

\section{Submit your article to this journal ๘}

џ Article views: 175

Q View related articles $₫$

View Crossmark data $\nearrow$ 


\title{
Creating capacities for peacebuilding citizenship: history and social studies curricula in Bangladesh, Canada, Colombia, and México
}

\author{
Kathy Bickmore, Ahmed Salehin Kaderi and Ángela Guerra-Sua \\ Ontario Institute for Studies in Education, University of Toronto, Toronto, Canada
}

\begin{abstract}
Public education is one influence on how young people learn to navigate social conflicts and to contribute to building democratic peace, including their sense of hope or powerlessness. Social studies curricula, in particular, introduce core concerns, geographies, governance and civil society, and participation skills and norms. History education narratives frame identity, (dis)trust or peaceful coexistence, and provide exemplars of how social conflicts and injustice have been handled in the past. To shed light on these peacebuilding and peace-blocking choices, this paper examines governmentsanctioned social studies and history curricula in contrasting contexts of violent conflict and peace: Bangladesh, Colombia, México, and (Ontario) Canada. Our comparative analysis shows how these official curricula (de)normalize violence and militarism, present national identities as hegemonic/exclusive or plural/inclusive, and create opportunities for teaching/ learning peacebuilding citizenship competencies such as conflict dialog, human rights awareness, and engagement in collective processes of civil society and governance.
\end{abstract}

\author{
ARTICLE HISTORY \\ Received 2 April 2017 \\ Accepted 15 July 2017
}

\section{KEYWORDS}

Peace education; history; social studies; citizenship education; international comparative curriculum

\section{Introduction: spaces for peacebuilding education in ordinary school curricula?}

Across much of the world, large proportions of young people are disenchanted, disengaged, or excluded from constructive democratic participation in social problem-solving, thus from helping to build sustainable peace (Kassimir and Flanagan 2010). While schools are by no means the only source of these problems, they are among few public institutions that can mobilize to do something about it (Bickmore 2017; Lopes Cardozo et al. 2015). International cross-cultural comparison of curricula can help to disentangle the threads of possibility and challenge in such an effort (Steiner-Khamsi 2004), while avoiding 'mindless cross-cultural transfer' of 
ideas (Jansen 2009, 240). Here, we compare government social studies and history curriculum documents in four very different conflict zones.

How may public education inform diverse people's capacities to nonviolently and justly handle conflict - that is, to engage democratically in helping to build peace? We assume that conflicts (such as competing values or interests) are inevitable in life, whereas violence (inflicting intentional harm) is not. Responses to conflicts reflect moral and political decisions, informed by people's understandings, relationships, and capacities (Ury 2000).

The overlapping goals of peacebuilding, peacemaking, and peacekeeping articulated by Galtung (1996) form the analytical foundation for this paper. Peacebuilding refers to comprehensive social change, toward social-political equity and cultural inclusion, repairing direct and indirect root causes of destructive conflict by (re)creating sustainable inclusive processes for ongoing constructive nonviolent conflict. Peacebuilding is comparable to Lederach's (2003) notion of conflict transformation. Peacemaking is democratic dialog for collective decision-making to resolve direct conflicts, once they have become visible. Peacekeeping, in contrast, refers to mechanisms of control for security, which can either facilitate or impede democratic peacemaking and peacebuilding. Gentle forms of peacekeeping (such as teaching anger management or rule following) can contribute to the acquiescent self control that Foucault (2011) calls governmentality. Yet, peacekeeping also may offer temporary safety that could enable more fundamental peacemaking and peacebuilding to begin (Bickmore 2015b).

Agency for peacebuilding citizenship includes both capacities - knowledge and competencies for transforming conflicts and altering structures to affirm justice - and motivations - hope, commitment, and moral judgment to make difficult choices. Peacebuilding education thus includes citizenship education.

Worldwide, education is a resource that is unequally distributed, which exacerbates social tensions (Bartusevičius 2014; Justino 2016). In particular, students have inequitable access to quality democratic citizenship learning opportunities (Schulz et al. 2010), thus to resources for developing well-informed agency to handle social conflicts. Especially in high-conflict contexts, there is a mismatch between the citizenship usually offered in schools and the citizenship actually enacted and intended by many young people (Barton 2015; Davies 2011; Torney-Purta and Amadeo 2011).

Education for peace cannot occur in a vacuum, but in response to its contexts. Official history and social studies curricula in any country create opportunities and barriers for building young citizens' capacities to participate in the daily work of building democratic peace. Social studies education may acknowledge or deny contemporary social, geographic, economic, and political problems, and examine or not the worldviews of diverse social actors, institutions, and processes through which decisions are made in addressing such conflicts. Similarly, history education may compare diverse stakeholders and conflict management choices with present challenges, or not. Historical narratives taught in school may reinforce consensus around hegemonic and adversarial perspectives, or respectfully engage 
with contrasting perspectives to build social bridges and sensibilities for peace. Such official curricula constitute a menu of potential resources and spaces that may facilitate or impede teachers' work with students for just peace (Horner et al. 2015; Nieto and Bickmore 2017; Rubin 2016).

Below, we review literature shedding light on two overlapping facets of curricular spaces that may encourage or discourage democratic peacebuilding: subject matter content that: (a) normalizes (or questions) violence and war, and (b) excludes (or includes) pluralist historical and national identity narratives; and competency building opportunities for peacebuilding citizenship, including: (a) communicative skills and empathy for handling conflicts nonviolently, (b) fluency and openness in handling diversity and justice challenges, and (c) skills and inclinations for participation in collective governance and decision-making in the context of conflicts. Afterward, we examine the same two facets of curricular learning spaces actually provided in the official documents for social studies and history education, grades 5-10, in Bangladesh, Colombia, México, and Ontario Canada.

\section{Subject matter content: normalizing (or questioning) violence and war, exclusionary (or inclusive) historical and national identity narratives}

Curricular narratives may normalize or glorify enmity, militarism, and other violence (Davies 2005). In contrast, curriculum that engages students in interpreting the causes and consequences of social conflicts from multiple perspectives can help them develop affective, value, and cognitive capacities for democratic peacebuilding (e.g.). For instance, in Colombia and Guatemala, social studies curricula have blamed indigenous insurgent movements for impeding national stability and economic development, 'forcing' the state to respond violently (Bellino 2014; Schuster 2009). In India and Pakistan, curricula have encouraged inter-religious and 'ethnic' violence (Lall 2008). In Canada, too, selective curriculum narratives limit students' opportunities to examine the human consequences of war (Fine-Meyer 2013).

Narratives and cultural symbols (such as those embedded in any curriculum) may contribute to cultures of destructive conflict, exacerbating inter-group distrust (Ross 2007; Williams 2014). History education, in particular, may legitimize (or mitigate) enmity through narratives of past conflicts, in particular by silencing (or acknowledging) alternate perspectives and pluralist identities (Byrom and Riley 2007; Paulson 2015). For instance, one analysis reveals that when the liberal party was in power, Colombian textbooks highlighted blame narratives about conservatives, and the same (against liberals) occurred when conservatives were in power: texts presented the opposing political group as barbaric, and justified their parties' own actions (Rueda 2008). Bangladesh curriculum, similarly, has represented hegemonic conflict narratives as singular truths, silencing alternate perspectives (Ghosh 2012). When one hegemonic version of the past is presented, especially when it blames an 'Other' for the outbreak and persistence of violent conflict, this raises fears and impedes understanding of complex realities (Anne Tupper 2014; 
Bekerman and Zembylas 2012; Davies 2005; Vanner, Akseer, and Kovinthan 2017). Clearly, such curricular narratives may reinforce or challenge the understandings students develop outside school, linked to their own ethnic-racial, religious, and gender identities (Barton and McCully 2012; Bellino 2015a; S. Levy 2014).

Often, curricula omit difficult histories, conflictual issues, and recognition of injustices or suffering, in order to avoid tensions or any demand for a moral response (van Ommering 2015; Paulson 2015; Sheppard 2010). For instance, Colombia's official curriculum guidelines have omitted any study of Colombia's recent violent history until grade 10 (Toro 2015). Particularly in violent conflict zones, textbook discourses acknowledging out-groups and human rights violations are relatively rare, although this may be changing in some recent texts (Russell and Tiplic 2014). On the other hand, where curricular narratives represent human rights as already achieved, this too may normalize the status quo, by excluding narratives that challenge dominant structures, promoting a citizenship of acquiescence (Kennelly and Llewellyn 2011; Lecamwasam 2015). Either way, such omissions limit students' opportunities to engage in reflection, discussion, or to imagine alternate possibilities: this can exacerbate feelings of powerlessness about reconciliation or achieving peace (Magendzo and Toledo 2009).

In contrast, history and social studies curricula may encourage peacebuilding by formulating learning opportunities in which young people can question, supplement, or replace particular enemy narratives, through inquiry about alternative narratives and alternate information sources. Including in curricula the stories of women, children, elderly and indigenous people facing racism, sexism, or exclusion may help students to understand historical and continuing effects of conflicts (Bajaj and Acosta 2009). Engaging voices (texts) from differing political, religious, or racialized identity groups may inform creation of peacebuilding narratives of solidarity or complementarity (Funk and Said 2004; McCully 2012). For instance, current history curriculum in Northern Ireland critically engages young citizens with their violent past and contemporary lived experience, acknowledging various perspectives (Barton 2015). Some Guatemalan history curriculum invites students to analyze the actions of both sides in their armed conflict (Bellino 2015b). Juxtaposing various parties' narratives and perspectives may help students to understand the causes, escalators, and consequences of conflicts, to develop their critical skills, and to awaken empathy (Bermúdez 2015; Helmsing 2014).

\section{Competency building opportunities for democratic peacebuilding citizenship}

Curriculum may make visible the moral (including political) choices implied by conflicts, and build participants' competence to participate in communicating across difference, making decisions and carrying out action for peacebuilding change. For injustices, values clashes and disagreements to be handled democratically and nonviolently requires citizen capacity to engage in processes and 
skills of communicative conflict resolution, decision-making, and social change addressing the roots of conflicts (Bickmore 2014b; Kaderi 2014). Without accessible school curriculum for developing such democratic competencies, the oppressed in particular may be limited to a narrow repertoire of options for responding to conflict, particularly violence, or docility reflecting governmentality (Foucault 2011) or internalized oppression (Fanon 2004).

Communicative skills and openness, to recognize and address the concerns of diverse parties, are keys to peacemaking (Harber and Sakade 2009). Long-term sustainable democratic peacebuilding includes peacemaking, plus capacities to collectively transform cultural patterns and to (re-)build social and political structures that have caused harm (Galtung 1996). Thus peacebuilding citizenship involves not merely skills, but also moral judgment capacities to recognize the concerns of dissenters and out-groups (Lauritzen 2016). Dialogic problem posing pedagogies, eliciting and critically examining lived realities - including diversity and justice questions - can encourage development of mutual understanding (re-humanization), equitable relationships, and democratic problem-solving capacities (Akar 2016; Barton and Levstik 2008; Freire 1970; Gill and Niens 2014; Lederach 1995). As Davies (2014) argues, these lofty goals require 'educative turbulence' and 'social collision,' not premature (assimilatory) attempts at 'social cohesion.' This means curricular opportunities to encounter and engage with conflicting identities, perspectives, and justice claims.

However, implemented history and social studies curriculum in formal public schools rarely involves much pedagogy of inquiry or discussion about conflictual issues (e.g. Hess and Avery 2008; Shuayb 2012). Where government curriculum guidelines neither require nor guide inclusion of difficult topics and challenging pedagogies, teachers may feel unprepared, fear losing their jobs, and consequently refrain from teaching about conflictual questions and perspectives (Patterson 2010). Especially in escalated conflict zones, educators often have valid fears that issues discussion involves risks, especially in contexts of political mistrust (Quaynor 2011). Certain content may be considered obscene, difficult, or dangerous in a given context, due to the emotional responses that may be elicited (Evans, Avery, and Pederson 2000; Sheppard, Katz, and Grosland 2015). Yet, avoiding conflicts in curriculum means marginalizing minority perspectives, thereby reinforcing ignorance and stereotypes. Artificially 'balancing' curriculum by carefully presenting 'both sides' of controversies, as well, may actually minimize opportunities for deepening understanding (Barton and McCully 2012). So, it's risky, but curriculum disconnected from the politics of contemporary problems reflects missed opportunities for peacebuilding citizenship education, and leaves teachers unguided and vulnerable when they do address conflictual issues.

Teachers often have not experienced, either as students or in their own training, inclusive student-centered active pedagogies that meaningfully confront conflict and difference. However, curricular incentives and professional guidance can help teachers develop competence and confidence to facilitate specific pedagogies, 
including democratic issues deliberation such as 'structured academic controversy' and restorative peacemaking dialog circles (Avery, Levy, and Simmons 2013; Bickmore 2008, 2015a). Similarly, collaborative learning and case study pedagogies can facilitate student investigation, interpretation, and meaningful dialog on conflictual questions (Jenkins and Jenkins 2010). Well-structured inter-group dialog pedagogies also can increase participants' pluralist respect and trust as well as communicative skills (Griffin, Brown, and warren 2012; Gurin-Sands et al. 2012). Such curricula may begin by addressing conflicts that are distant (in time or location) from students' own contexts, thus less polarized, and gradually develop students' capacities to address more complex and locally sensitive past and contemporary issues (King 2009). There are pedagogical tools to 'indirectly' facilitate some peace-related skill building, even in sensitive political contexts where 'direct' peace education content is not feasible (Bar-Tal, Yigal Rosen, and Nets-Zehngut 2010).

A related, under-taught set of peacebuilding competencies (that builds on all of the above) centers on democratic governance and civil society participation to alter patterns of destructive conflict. Prior research shows that Bangladesh social studies curriculum rhetorically encourages citizenship engagement, but primarily by glorifying youths' violent heroism in response to past injustices (Ghosh 2012). Canadian curricula tend to emphasize individual character and passive multicultural respect far more than fundamental social reform addressing structural injustice through politics (Bickmore 2014a; Tupper and Cappello 2012). Similarly, Mexican and Colombian convivencia (living together peacefully) goals enshrined in contemporary curriculum documents, emphasizing interpersonal skills and compliant values, are remarkably different from the original broad meaning of convivencia: cooperative coexistence and inclusive political structure among differing identity groups (Lovat and Crotty 2015; Schulz et al. 2010).

Thus, as the document analysis below confirms, government curricula generally include some dimensions of peacebuilding citizenship knowledge and competencies, but the curricula examined are insufficiently comprehensive to equip young people for constructive democratic action to transformation toward just, sustainable peace. It is our hope in this paper, by highlighting different dimensions and curriculum policy choices in contrasting contexts, to inform the deepening and broadening of peacebuilding education opportunities in public schools.

\section{Contexts for curriculum}

Bangladesh, Canada, Colombia, and México are imperfect democracies, each experiencing widespread concern about aggression, lethal violence, social inequalities, and citizen (dis)engagement (Abrego Franco 2010; Guevara and Tirado 2006; Jaramillo and Mesa 2009; Siddiqi 2011). Bangladesh, ranked 83 of 163 countries on the Global Peace Index (IEP 2016), experiences moderately high social exclusion and direct violence, including escalated political violence between supporters 
of rival political groups. Canada, ranked 8 (peaceful) on the Global Peace Index, is a relatively tranquil multicultural settler context, although direct and indirect violence are still pervasive in economically and racially marginalized communities. Colombia, ranked 147 on the Global Peace Index, is in the process of reconciliation and repair after a half century of civil war which has displaced, injured, or killed an enormous proportion of the population. México, though not generally defined as a war zone, is ranked 140 on the Global Peace Index, based on a different kind of internal armed conflict: displacement and murder associated with drug gang and military/police activity.

Political violence has become common in post-independence Bangladesh: young citizens are often either violently engaged in political rivalry (Macdonald 2016) or disengaged (Riaz and Raji 2011). Political leaders have often mobilized identity-based nationalism, including religious militancy, presenting certain expressions of Islamic identity as being in opposition to Bangladeshi national identity (Gohel 2014; Islam 2011). Such legitimized violence has thwarted Bangladesh's democratic culture (Ahsan and Banavar 2011). Some official curricula in Bangladesh have been shown to encourage compliance with the dominant political status quo and neoliberal global market economy (Alam 2011, 2012). One study (Islam 2014) does report some peacebuilding-relevant human rights, development, and civics content in some textbooks. In other parts of southern Asia, a few curricula also provide learning opportunities relevant to peace, citizenship, human rights, and sovereignty (Bajaj 2016; Sri Lanka Guardian 2017).

Public schooling is a provincial responsibility in Canada, so this project examines the curriculum of one large central province, Ontario. In contrast to the goals of much implemented citizenship curriculum here, Canadian youth often express disinterest in formal political participation, instead favoring direct engagement to address problems of personal interest (Hughes and Sears 2008). Students sometimes repeat mainstream citizenship notions taught in school - such as the importance of voting, environmental care, or charity - without intending to act accordingly (Chareka and Sears 2006; Llewellyn and Westheimer 2009). Some racially and economically marginalized youth have expressed a contradictory sense that people like themselves were at fault for their own marginalization (Kennelly and Dillabough 2008). Evidently, Canadian history and social studies education may be mismatched with the experiences of students, especially racialized and non-affluent youth (Bickmore 2014a).

Colombia's Government recently reached a peace accord with a major insurgent group, after over 50 years of civil war resulting in over six million internally displaced people (Norwegian Refugee Council 2015). Colombia faces high rates of homicide associated with organized crime, domestic violence, delinquency, and political insurgency (De la hoz 2013; Gagne 2015). This enormous level of violence, and young citizens' frequent disengagement from constructive civic activity, prompted the 2004 launch of a National Program of Citizenship Competencies that aims to develop cognitive, emotional, and communicative skills to support 
democratic participation, respect for diversity and living peacefully with others (Ruiz and Chaux 2005). Further, in 2015, the government launched a cross-curricular requirement to implement peace education in relation to Colombia's land, culture, social context, and historical memory into learning activities in every school (Camargo 2016).

México is also undergoing a period of escalated violence. In one student survey, about $20 \%$ reported 'some or much violence' at their recent school and $15 \%$ in the surrounding community (Reimers and Cardenas 2010). Like many youth across the world, most surveyed Mexican youth had engaged in 'private solidarity' activity such as charity; many had volunteered in their communities. However, they expressed disinterest, distrust, and lack of knowledge about formal politics, and reported participating in civic organizations or political parties less frequently than Colombian youth; they felt citizens had little influence over the powerful (Reimers and Cardenas 2010; Schulz et al. 2011). Surveys of Mexican secondary students found little understanding of democratic ideas such as equitable involvement of women or minority groups in politics or fairly elected representation (Guevara and Tirado 2006; Schulz et al. 2011). México incorporated a new social issues-based junior secondary Civics and Ethics course in 1999 (Tirado and Guevara 2006).

In all four contexts, institutional pressure to transmit large amounts of information often 'prevents inclusion of the students' experience and imposes contexts that relate exclusively to students from upper (or upper middle) class backgrounds' (Tibbitts and Torney-purta 1999, 17; also Lopes Cardozo et al. 2015).

\section{Methods}

This analysis of official curriculum documents is part of a multi-year international qualitative study, 'Peace-Building Citizenship Learning in Comparative Contexts affected by Violence: School Connections with Life Experience.'Project schools are located in non-affluent, violence-affected urban areas in four countries that differ markedly in their approaches to social and political conflict (Bickmore, Awad, and Radjenovic 2017). Participants are youth ages 10-15 - a key period for developing citizenship inclinations and capacities to handle social conflicts (Torney-Purta and Amadeo 2011) - and their teachers. Social studies and history curricula were selected for this paper because they represent explicit locations for peace- and citizenship-related education, addressing both historically rooted and contemporary conflicts.

Our research question is: How do official curriculum guidelines in the four contexts address social conflict problems relevant to non-affluent young people living in contexts of violence, and the options available to address those problems? Specifically, our analysis of government history and social studies curriculum documents of Bangladesh, Colombia, México, and Ontario Canada shows how curricula may create opportunities and challenges for (upper elementary and junior secondary) students to build capacity and inclinations for peacebuilding citizenship participation. 
Curriculum documents analyzed include Bangladesh and Global Studies, compulsory for grades 5-8 and for one academic stream in grades 9-10 (optional in other streams), which includes history, social development, human rights, governance, and geography (Bangladesh, National Curriculum and Textbook Board 2012a, 2012b). Colombian guidelines are non-compulsory: social sciences grades 5-10 and citizenship grades 5-9 (Colombia, Ministerio Nacional de Educación 2006a, 2006b). Mexican compulsory course documents include: geography grades 5-7; history grades 5, 6, 8, \& 9; civics/ethics grades 5, 6, 8, \& 9; the citizenship grade 7 course is mandated by the state of Guanajuato (México, Secretaría de Educación Pública 2011a, 2011 b, 2011c, 2011d). Ontario (Canada) compulsory courses include: social studies grades 5 and 6 , history grades $7,8,10$, geography grades $7,8,9$, and civics grade 10 (Province of Ontario 2013a, 2013b).

The Ontario Canada and Bangladesh curricula represent government mandates with detailed learning expectations and suggestions for teacher pedagogy. The Mexican curriculum also represents government mandate, but contains considerably less detail: as in Bangladesh, government-approved textbooks, not analyzed here, fill out curriculum mandates in practice. In contrast, Colombian curriculum documents (like Mexico's, not very detailed) represent prevailing discourses and goals for schools, but are considered guidelines: schools have considerable autonomy.

An analytical rubric to inform initial synthesis of document content was initially derived from the literature. Various rounds of interpretation informed further data collection and analysis (as in Charmaz 2000). We describe each curriculum's inclusion, exclusion and interpretations of various social conflicts and violence and their causes, and the potential government or citizen actions that may help to mitigate them. For instance, we note how documents represent singular or multiple points of view, and opportunities or impediments for students to practice elements of citizenship participation (such as discussion or inquiry) in addressing such problems.

\section{Results}

Below, we first attend to curriculum content, specifically how each official curriculum normalizes (or questions) the use of violence and military force and the representation, negation or inclusion of monolithic and/or alternate identity-linked historical narratives and perspectives. Next, we examine curricular spaces for students' development of procedural knowledge (competency), values and confidence for peacebuilding citizenship, including conflict awareness and communicative conflict resolution skills, recognition and practice of diversity and human rights, and capacities for participation in collective governance and decision-making processes. 


\section{Curricular content: normalizing (or questioning) violence and war, exclusionary (or inclusive) historical and national identity narratives}

The Bangladesh and Global Studies curriculum document normalizes war and violence through narratives that represent violent retaliation as the only feasible response to conflicts with (ostensible) enemies or oppressors. For example, it presents 'Pakistani soldiers' oppressions and tortures during the war of independence,' and glorifies 'the protests, movements, and guerrilla movements of the freedom fighters against the Pakistani soldiers' (BGS 6). The curriculum offers no space for alternative perspectives.

History chapters in the Bangladesh curriculum emphasize the innocence of the Bengali people and how various evil groups - including the British and Pakistanis - have wronged them. Students are recurrently required to learn dominant narratives of Bangladesh's creation and continuing conflicts, particularly the violence between West and East Pakistan and the causes and significance of a 1969 Bangladesh public uprising (BGS 7). Bangladeshi citizenship is represented as the spirit of an independent, united people fighting British and Pakistani oppressions:'following the spirit of independence, be[ing] encouraged in patriotism and nationalism, build[ing] the attitude of sacrificing, and be[ing] active participants in matters of nation-state building' (BGS 5). Thus, Bangladesh and Global Studies curricular narratives do not avoid conflict, but do impede recognition of alternative perspectives.

A few Ontario (Canada) curriculum expectations link war participation with Canadian identity, for instance in examining war memorials (Social Studies 6), or in justifying Canadian participation in particular wars (History 8: 'Why did Laurier compromise on the issue of sending Canadian soldiers to fight in the Boer War?'). Military peacekeeping intervention is proudly presented as a Canadian invention and priority. Beyond these few examples, the Ontario curriculum also offers several opportunities for students to consider the consequences of wars for diverse social groups, and sometimes to consider alternatives.

Ontario (Canada) curriculum narratives encourage respect for military heroes of various wars, but rarely in ways that glorify military heroes or demonize enemies. It sometimes requires students to critically examine alternate parties' experiences of conflicts. For instance, students are to examine various'aspects of the interactions among and between [indigenous] First Nations and Europeans in Canada ... from the perspectives of the various groups involved (such as settlers, coureurs de bois, missionaries, Filles du Roi, First Nations women, warriors, and/or shamans)' (Social Studies 5). The perspectives of indigenous people are implied, but not informed, by curriculum questions such as, 'Who are the founding nations of Canada? For whom is the concept of "founding nations" troubling? Why?' (Social Studies 6).

Colombian curriculum, like the others, presents wars as pivotal historical moments, including the impact of the French Revolution on Latin American independence movements (Social Sciences 8), and the influence of Colombia's 
'Violence' period (1948-1958) on subsequent armed conflict (Social Sciences 10). It also presents some opportunities to assess consequences of violence, usually without including all affected parties. Like the other three countries' curricula, the Colombian social sciences curriculum does not include alternatives to war. However, it does encourage prevention of interpersonal conflict escalation through development of empathy, caring, and constructive communication skills (Citizenship 5 \& 9).

When the Colombian curriculum finally addresses the armed conflict in grade 10 (having ignored it in earlier grades), it points to internal enemies and normalizes military securitization. For instance, students are to 'explain the emergence of guerrillas, paramilitaries and drug traffickers in Colombia ... to the present day' (Social Sciences 10). Insurgents are represented as an illegitimate Other, the threat to peace. In this selective narrative, the role of the national army and continuing social injustices are not addressed. The curriculum omits the voices of victims, revolutionaries, and other narratives that could enlarge the understanding of the conflict. This represents a missed opportunity for students to investigate structural impediments to democracy and peace, or to imagine potential solutions to end the armed conflict.

The Mexican history curriculum addresses past conflicts, usually without probing the motives of actors or the consequences for non-dominant parties. For instance, students are to 'value the legacy that the [Mexican] revolutionary culture has left in the present' (History 5). Various wars (French, Chinese, Russian, México against USA, World Wars, Arab-Israeli) are presented as important milestones, without students being encouraged to imagine alternative ways conflicts might have been solved.

Mexican history curriculum mandates present a singular nationalist narrative, highlighting the roles of particular insurgent military leaders in the Mexican Revolution (such as Zapata, Villa, Carranza, Obregón) and implicitly excluding other narratives although not demonizing enemies (History 5). However, students are to examine the role, struggles, and resistance movements of the working class during the Industrial Revolution (History 8). Also, curriculum mandates include the role of women in World War II and their resistance movement to acquire the right to vote (History 8). Thus in México, there are occasional opportunities for students to examine selected alternative narratives in relation to some conflicts, and not others.

However, as in Ontario and Colombia, Mexico's issues-based Civics and Ethics course encourages students to discuss diverse points of view and to build consensus around some contemporary conflicts, primarily local and interpersonal, within a framework of respect for law and rejection of violence (Civics and Ethics 8, 9). Accordingly, this course (but, as in Colombia, not other social sciences courses) presents opportunities to question violence and to practice peacemaking skills.

In sum, in the four curricular jurisdictions examined, armed force was occasionally contested but mostly legitimized. Recently initiated explicit citizenship 
courses in México, Ontario Canada, and Colombia, however, partially contradicted this message by emphasizing interpersonal peacemaking, tolerance, and other democracy related skills and values.

Each of the four government curricula acknowledge to some degree within-country diversity, alongside large-scale conflicts between an imagined national community ('us') and one or more 'Others' inside or outside the country. In Ontario Canada and in some of the recent history and contemporary social studies in México, curriculum mandates allow for (but don't fully support) students to grapple with the moral messages in alternate narratives about particular social conflicts. Colombian and Bangladesh curricula appear more constrained by single hegemonic narratives wrapped up in recent wars, thereby narrowing the space for student development of empathetic comprehension of in-groups, out-groups, and the consequences of violent conflict - especially beyond the interpersonal level. In all four jurisdictions, there are few explicit opportunities for students to probe the historical roots of contemporary conflicts, to shed light on alternate viewpoints regarding potential actions in current struggles for democratic rights and peace.

\section{Competency building opportunities for democratic peacebuilding citizenship}

\section{Communicative skills and empathy: facing conflicts nonviolently}

The curriculum documents we examined did include, to varying degrees, a few opportunities to analyze examples of social conflicts: causes, consequences, and (rarely) potential democratic solutions, occasionally in relation to multiple stakeholders and their interests. These included some conflictual historical moments with continuing legacies, such as colonial relations between settlers and indigenous peoples in Canada, and contemporary issues such as rural poverty in Colombia and México and violent political rivalry around elections in Bangladesh.

In Bangladesh and Global Studies, certain contemporary social problems over population (BGS 5); corruption, violence against women, child abuse, child marriage, child labor, and child trafficking (BGS 6, 7, 10); terrorism (BGS 10); and challenges in carrying out fair, nonviolent elections (BGS 7, 10) - recur in multiple grades. For instance, pedagogical guidelines say students should write reports on how much the people in their neighborhoods abide by proper nonviolent behaviors during election campaigns.

The Bangladesh and Global Studies curriculum suggests almost no peer discussion, beyond one instance of 'remembering a local freedom-fighter in the classroom and exchanging views' (BGS 6, 9-10). It does not link reading, writing, listening, speaking, or other social skills to peacebuilding or citizenship. Dialog, problem-solving, conflict resolution, or collective decision-making goals virtually never appear in the Bangladesh curriculum documents reviewed. 
Ontario Geography grades 7-8 and History grade 10 include recurring opportunities for inquiry skill development potentially relevant to conflict analysis, such as consulting multiple sources of evidence. Students are to examine how several non-recent historical conflicts evolved - acknowledging positive and negative consequences for multiple stakeholders, for instance in relation to early indigenous-European interactions and Loyalist migration (History 5, 7). Students are to investigate various Canadians' perspectives on early twentieth-century science and technology developments such as penicillin, radar, and the atomic bomb (History 10). Explicit opportunities to study contemporary conflicts are rare in Ontario's curriculum, although current events are mentioned as 'strands' in Geography 9 and History 10. Expectations regarding the causes and consequences of global development (Geography 8) and extraction of natural resources (Geography 9) do not mention, but could be applied to, contemporary conflicts.

Requirements to respectfully communicate diverse ideas appear just twice in Ontario's grade 9 Geography. Decision-making and negotiation processes are largely absent from Ontario's history and social studies curriculum, except somewhat in the grade 10 Civics half-course, although there are occasional mentions of 'problem-solving strategies.'

As in Ontario, Colombian students are to learn potentially pluralist inquiry skills of locating, assessing, and referencing evidence from diverse sources. Colombian social sciences guidelines also examine causes of some non-recent armed conflicts: the war of independence and the separation of Panama (5), medieval land disputes (6-7), the French Revolution (8-9), and World Wars (10). The document does not mention alternatives to war, nor particular social groups affected. Similarly, the curriculum addresses environmental degradation, but avoids probing the sources of such problems, instead advocating individual responsibility such as recycling and limiting personal consumption (Social Sciences 4-5). Particularly beginning in eighth grade, students are to compare past events, such as nineteenth-century migration, to contemporary conflicts - although without addressing potential solutions. Uniquely, the Colombian Citizenship course expects students to examine the concerns of various parties, and to propose fair solutions, in interpersonal conflicts (5). It invites older students to analyze discourses that legitimize human rights violations in relation to their own experience (8-9). Thus at the interpersonal level, and just slightly in relation to social scale problems, Colombian students are to be taught how conflicts can be positive opportunities to strengthen social relationships.

Mexican history curriculum examines causes and some consequences of certain past armed conflicts - such as the Mexican Revolution (5), Latin American independence movements, and World Wars (8) - similarly without addressing potential alternate solutions. Geography (5-7) and Civics/Ethics (5-9) courses address several contemporary conflict issues including poverty, malnutrition, migration, refugees, urban/rural differences, drug abuse, and the causes and potential solutions of domestic violence, although without allocating sufficient time for depth. One 
civics unit addresses violence in students' own neighborhoods. The history curriculum $(5,9)$, too, occasionally says students should propose solutions to current Mexican issues. History 8 and Geography 5 mention environmental problems such as global warming and environmental catastrophes - mainly without presenting or inviting multiple perspectives, and, like Colombia, emphasizing limited individual solutions such as not littering. The Mexican curricula reviewed, like the Bangladesh curricula, did not articulate the critical inquiry skill of assessing and referencing multiple sources of evidence that might address multiple points of view.

Colombian and Mexican social studies curricula, similarly, emphasize mutual tolerance, social cohesion, and complying with norms. Colombian students are to agree upon and comply with norms at school and home (Social Sciences 5-10). Mexican students are to'recognize that norms represent social accords that support democratic cohesion' (Civics/Ethics 5). They are supposed to learn 'to use mechanisms to control their anger, including breathing deeply, counting to ten and avoiding confrontations' (Citizenship 5-10). Similarly, México requires students to 'regulate their emotions and impulses' (Civics and Ethics 5). Thus, these programs are oriented toward teaching self-regulation skills and dispositions - gentle peacekeeping, not peacemaking.

However, Mexican, and especially Colombian curricula sometimes expect students to carry out some peacemaking: to reach mutual understanding by considering others' feelings and points of view and by expressing thoughts assertively, not aggressively. Mexican students occasionally are encouraged to use (although teachers are not clearly required to teach) negotiation and dialog processes (Civics and Ethics 6). Some Colombian curriculum encourages discussion pedagogies, such as to 'participate in debates and discussions, assuming a position and being able to modify it by considering others' points of view and arguments,'emphasizing the value of respect toward others' viewpoints (Social Sciences 5-10).

Remarkably, among the four sets of history and social studies curricula, only the citizenship course in Colombia, and to a limited degree the civics courses in México and in Ontario, require any guided practice in actual communicative processes for dialog and resolution of conflict - to repair relationships and solve problems after disputes or aggression, and to provide a foundation for further peacebuilding citizenship learning. Bangladesh and Colombia curricula mention several contemporary and historical conflicts, and México's civics addresses contemporary issues - yet, these expectations rarely consider multiple stakeholders. Individual character and values goals (showing empathy, respecting selves and others, cooperating, respect for internationalism) are emphasized in all four jurisdictions' curricula. Such lessons could support some aspects of peacemaking, but they also could impede open exchange of views.

Thus, students in all jurisdictions have limited, or in Bangladesh vanishingly rare, opportunities to learn or practice peacemaking skills and processes with which to constructively communicate about conflicts. Educators are not explicitly required or supported, except in the Colombian citizenship course, to teach specific 
conflict resolution or dialog processes. To inform students' peacebuilding skills and judgment capacities, curriculum would need to acknowledge the existence of conflicts, and teach alternate (nonviolent) options for handling various parties' conflicting concerns.

\section{Handling diversity and justice challenges}

A crucial element of peacebuilding citizenship capacity is the recognition and handling of diverse viewpoints, social identities, and social-structural locations. This means respectfully acknowledging and critically interpreting contrasting perspectives and values, in light of diversity, unequal power, and human rights goals - including critically examining various instances of injustice and ways to equitably accommodate all members of society. Social diversity (only sometimes accompanied by questions of equity) appears frequently in each jurisdiction's curriculum.

Bangladesh curriculum frequently mentions diversity within the country, such as women's quality of life in relation to dowry injustices (BGS 7). It tells students to show respect for diverse cultures, naming Bangladesh's aboriginal groups (BGS 8). Bangladeshi students are required to explain the status of child rights in their neighborhood, to demonstrate how they could solve socio-economic problems in Bangladesh, to identify the causes and effects of child marriage and juvenile delinquency in their neighborhood, and to propose how to prevent smoking in their school (BGS 6-8). However, the documents virtually never mention identity group members' own perspectives about their needs and concerns, nor how well they are accommodated. Similarly, there is no mention of tensions around accommodation of Islamic diversity or Bangladesh's Hindu population, implying that pluralist solidarity already has been achieved.

Bangladesh curriculum mandates occasionally invite students to 'evaluate' aspects of historical and contemporary conflicts, such as the impacts of British colonial rule and how independence 'freedom fighters' were supported or not by Bengalis and others (BGS 6-8). Although the term 'evaluate' seems to invite higher order thinking and diverse viewpoints, this would be difficult to implement in practice, since the curriculum offers virtually no examination of conflicts' causes or of contrasting perspectives. Such a partial curriculum mandate would not inform, require, or reduce teachers' risks to open inquiry about alternate viewpoints.

Ontario students are expected to recognize the concerns of various Canadian identity groups, and occasionally to acknowledge the absence of equitable accommodation for some of them. For instance, students are to analyze'how various factors have affected the economies of specific developed and developing countries around the world' (Geography 8), and to investigate child poverty on indigenous reserves or in cities, homelessness, and access to healthcare (History 6).

However, some fundamental debates around social and political accommodation of ethnic and religious diversity rarely appear in the Ontario history and social studies curricula reviewed. The documents never mention gender-based violence. 
Once, students are to 'evaluate' how much multicultural inclusiveness and freedom of religion 'Canada has achieved' in relation to the Canadian Charter of Rights and Freedoms and the Ontario Human Rights Code (History 6). The document implies (as in Bangladesh) that various identity groups' human rights are largely already achieved in Canada: this could impede inquiry and open dialog for democratic peacebuilding learning.

Colombian curricula present the values of respecting human differences; children's rights to education, healthcare, livelihood and recreation; and the rights of internally displaced persons (Social Sciences 5-10; Citizenship 5). Some gender equity rights (including reproductive and family planning choice) are presented in the citizenship course. Issues of discrimination are usually addressed in generic terms, emphasizing individual differences without mentioning specific groups or issues, except when referring to the distant past - slavery, the Inquisition, and women's right to vote (Social Sciences 5-10; Citizenship 6). Even in addressing the cultural, political, and economic legacies of the encounter between Africa, the Americas, and Europe, conflictual relationships are just once obliquely mentioned, referring to the abolition of slavery in nineteenth-century Colombia (Social Sciences 8-9). Social Sciences (8-9) curricula present the artistic legacies of indigenous Colombian people, omitting mention of racism and neocolonial conflicts that these groups still endure.

However, unlike the other social sciences courses, the Citizenship course does address discrimination, social exclusion, and poverty in Colombia. In younger grades, it encourages students to question how their own actions could reinforce violation of rights (Citizenship 5). Older grades (8-9) curriculum mentions specific groups (women, minority ethnic groups, homosexuals) who have had their rights denied - as in the other jurisdictions, presenting these problems as largely past and not examining how these groups have voiced their concerns.

Mexican curricula address some human rights content. A few history lessons (8-9) examine how citizens in the past defended their rights - such as workers in the Industrial Revolution, the student movement of 1968, peasants' unions for agrarian reform, and women's voting rights movements. Similar to Colombia, Mexican curricula present cultural features and legacies of indigenous peoples in relation to the distant past, celebrating the post-Conquest mixture of races (mestizaje), without acknowledging contemporary indigenous roles or justice conflicts (History 5-6; Geography 5-7).

Civics/ Ethics $(6,8)$, in contrast, addresses contemporary inequities based on 'ethnocentrism, national or ethnic origin; sex, age, disability; social or economic conditions; pregnancy; language, religion, political opinions; sexual preferences or civil status.' Students are to 'question and reject discriminatory actions ... that may harm people's dignity' such as stereotypes in the media. Further, students are to identify leaders and social 'movements that achieved results in favor of equality' (Civics/Ethics 6). Studying such human rights concerns, and how people 
have acted to achieve change, may help students to imagine ways in which they could participate in transformative peacebuilding.

To compare, México's curriculum presents more opportunities than Colombia's to examine justice and human rights issues in relation to specific identity groups. However, Colombian curricula examine some social structural roots of discrimination, such as poverty, whereas México's emphasize only individual attitudes. Similar to México, Bangladesh emphasizes improving social relations by advocating humane personal qualities toward deprived children, women, and elderly people, without examining the roots of such injustice (BGS 6-8).

In contrast, Ontario curriculum documents rarely mention contemporary human rights violations within Canada. Such silencing would impede peacebuilding citizenship capacity building. Bangladeshi students have more explicit opportunities than Ontario students to link curriculum to their own experiences (although discussion is not advocated in pedagogical instructions), but less opportunity than Ontario (and, to some degree, the other jurisdictions) to study diverse identity groups' perspectives about social conflicts.

\section{Participation in collective governance and decision-making in the context of conflicts}

The key element of peacebuilding citizenship least addressed in the curriculum documents analyzed is students' capacity building to participate in collective decision-making and nonviolent social action, as democratic processes for transforming conflicts.

As mentioned above, Bangladesh curricula sometimes invite students to 'evaluate' governing processes, such as whether they believe people democratically choose their parliamentary representatives (BGS 6-8), and once propose a campaign to prevent violence against women (BGS 10). Students are not guided to examine how governance decisions might mitigate conflicts like child trafficking and environmental pollution (BGS 6). Instead, democracy is presented in generic normative terms:'assist the government to democratize the society by respecting and practicing democracy in every phase of their lives and by explaining how fellow citizens could be encouraged to practice democracy in their lives' (BGS 5). The curriculum describes 'the qualities of good citizens' as not doing bad things (such as damaging the environment), and obeying the principles represented as defining independent Bengalis.

Ontario Canada curricula do include some attention to government and citizen actions, for instance for sustainable social development (Geography 9; Social Studies 5). Ontario students are occasionally invited to plan local or transnational actions toward equity and justice, thus enacting their own viewpoints and an active citizen role - such as how to meet the needs of immigrants settling in different parts of Canada, how 'business opportunities, cultural enrichment, global engagement and citizenship' could be increased among immigrant populations, 
and to propose remedies to'neighborhood segregation and lack of social integration, hate crimes' (Geography 9). The few explicit prompts for students to express their own perspectives - for example about power shifts in colonial Canada (History 7) or Canada's participation in World War I (History 10) - are usually framed as optional. The need for democratization, human rights, and economic development is acknowledged primarily in relation to the past or to non-Canadian contexts - such that, as in Bangladesh, collective governance participation in altering current conflicts is rarely addressed. Only the grade 10 Civics half-course includes a citizenship engagement theme: students are to learn 'fundamental beliefs and values associated with democratic citizenship in Canada,' such as rule of law and multicultural equity. However, examples of such participation in this curriculum generally ignore formal politics: Ontario students are generally encouraged to contribute individually to their communities.

Colombian curriculum describes government and citizenship in ancient Greece, Inca civilization, the Middle Ages, the colonial era, and the twentieth century (Social Sciences 6-10; Citizenship 8-9). It compares various political systems implemented in Colombia, such as the citizenship participation mechanisms in the Constitutions of 1886 and 1991 (Social Sciences 5, 8-10). Once, students are to design a campaign to promote a culture of paying taxes (Social Sciences 10).

Mexican curricula identify the functions of each branch of government and formal participation mechanisms (Civics and Ethics 6, 8), such as 'why voting for a person that represents a social group is necessary' (Civics and Ethics 5). Students are to suggest ways to become better-informed citizens in order to participate, and to read public information in order to understand the main priorities of potential political leaders (Civics and Ethics 6,8). The emphasis, as in the other jurisdictions, is primarily information, duties and compliance.

However, México and Colombia, like Ontario Canada, occasionally ask students to identify local, national and international organizations that protect human rights, and encourage reporting human needs or rights violations to authorities (Colombia Social Sciences 5-10; México Civics and Ethics 8). Colombian and Mexican curricula mention student participation in school governance. Colombia suggests engaging students in developing in their classrooms' peaceful coexistence norms (Social Sciences 6-7); México highlights that students may be punished if norms are not followed (Civics and Ethics, 5), and should learn to listen others' perspectives in debates (Civics/ Ethics 9). One curriculum activity invites students to make proposals for 'alleviating unequal conditions of social groups that affect their personal and collective integrity' (Civics/ Ethics 6). Students are to find out about government policies to mitigate environmental problems (Geography 5). Identifying such specific organizational spaces where citizens can get help or take action is relevant for developing their agency and peacebuilding capacities.

In sum, there are a few potential opportunities in the Ontario Canada, Colombia and México (but not Bangladesh) curricula for students to learn not only basic civics information, but also occasionally how people in their contexts can access 
and participate in influencing civil society and government action on behalf of human rights and other peacebuilding.

\section{Discussion}

In sum, history and social studies curricula in all four contexts, to different degrees, normalize violence by glorifying war narratives and military heroism and ignoring alternate options for responding to conflict. Bangladesh and Colombia curricula tend to blame an 'Other' - Pakistanis or internal insurgents. Such enmity narratives block moral judgment for pluralist peaceful living, because people's identities and viewpoints are presented as wrong. The Ontario Canada curriculum is the only one of the four that regularly engages students with evidence-based analyses of diverse actors' viewpoints about the causes and possibilities represented by conflicts, thereby challenging hegemonic assumptions of a single contemporary or historical 'truth' narrative. On the other hand, although diversity appears in all of these curricula, students are usually expected to practice only individual humanitarian values, compliance and avoidance of violence. Such gentle peacekeeping emphasizes control, not democratic peacemaking or peacebuilding across particular social differences.

Developing capacity to acknowledge and handle conflicts as conflicts - as embodying competing perspectives or needs, the need for choice rather than mere absorption of 'truth' - is perhaps the foundation of democratic peacebuilding citizenship. Ethical-political judgment would be irrelevant if a person didn't know there were alternatives, and unworkable if they didn't recognize the humanity of those with conflicting perspectives. It is easy to recognize escalated violence and oppression, but school social studies and history can also teach students to look below and around the symptoms, and to recognize conflicts when they're smaller when they are most amenable to nonviolent resolution and repair. Dialog and negotiated resolution of conflict are key elements of peacemaking and peacebuilding (which can be improved with guided practice), as well as processes for helping citizens come to understand the diverse concerns of parties affected by conflicts. This foundational conflict awareness and communication was most clearly supported in the recently created civics/citizenship courses in Colombia, to some degree in México, and in Ontario Canada - thus in both relatively peaceful and unpeaceful contexts.

Fundamental to affirming just peace, beyond generic communicative conflict resolution and dialog skills, is a capacity to humanize across social differences, especially amid the particular challenges of inter-group division, social exclusion, and inequity conflicts. Curricula in all four jurisdictions recognized diversity, inequality, and systemic injustice in the misty past, although often without examining the roots of injustices. They were considerably more uneven in addressing human rights struggles and inter-group divisions in the present tense: each jurisdiction found a few such justice matters to touch upon, and avoided those considered 
sensitive in that particular context. For instance, Ontario Canada presented indigenous issues and gender inequities/violence as primarily past and resolved, contrary to the evidence of current events.

Bangladesh, and to some extent the other three jurisdictions, presented social injustice as primarily a matter of passive individual values such as tolerance - as if identity-linked social transformation were a matter of attitude adjustment, not redress of harm through changes in patterns of governance. However, México, Colombia, and Ontario Canada, occasionally presented the ways specific identity groups were affected by particular violence and injustice in particular historical moments, and sometimes how they acted in defense of their rights resulting in transformed social institutions: such exemplars offer grounding for democratic peacebuilding. To have hope as well as capacity to make nonviolent democratic choices, students need to know about social actions that aim to (or did!) achieve change.

Singular national history narratives, as frequently presented in Colombian and Bangladesh curricula, can have an emotional resonance yet leave little space for learners to become aware of their moral opportunity for choice. In contrast, examining multiple parties' narratives about historical and contemporary issues - for instance, contrasting sources that describe the same event from different viewpoints - may open up spaces for young students to build peace based on understanding the causes (human wants, feelings, worldviews and needs) that have triggered, escalated, or helped to resolve certain social conflicts.

Despite some opportunities for examining the causes and consequences of past and contemporary conflicts, curricula in all four contexts largely ignore nonviolent alternatives, especially social-scale collective decision-making, social action, and governance. All four curricula assume or promote the legitimacy of military force. Bangladesh curriculum also glorifies violent insurgent action. Colombia, México, and Ontario curricula mention some political changes accomplished in the past, such as new protections for workers or democratic voice, almost as if these governance reforms had occurred naturally, and these curricular mentions are disconnected from the basic information provided about contemporary structures and functions of each government. Thus, the social studies curricula in all four jurisdictions largely miss the opportunity to build capacity for collective democratic or democratizing political processes - values, skills, and understandings to act collectively for justice and peace.

What we learned from this comparative international curriculum analysis is that ethical and political education for democratic peace can be mainstreamed. Although we did not by any means find any perfect peacebuilding curriculum, we did find that all four jurisdictions found some context-appropriate, feasible ways to infuse some conflict awareness, dialog and self-expression skills, human rights, social justice and re-humanization perspectives into history, social studies, and especially explicit civics/citizenship curriculum. 


\section{Disclosure statement}

No potential conflict of interest was reported by the authors.

\section{Funding}

This work was supported by Social Sciences and Humanities Research Council of Canada [grant number 435-2013-0400].

\section{Notes on contributors}

Kathy Bickmore is a professor in Curriculum Studies and Comparative International and Development Education at the Ontario Institute for Studies in Education (OISE), University of Toronto. Her interests include conflict, peace-building and democratic education in K-12 public schools around the world.

Ahmed Salehin Kaderi, from Bangladesh, is completing his $\mathrm{PhD}$ in the same program at OISE. Ángela Guerra-Sua, from Colombia, is completing her $\mathrm{PhD}$ in the same program at OISE.

\section{References}

Abrego Franco, María Guadalupe. 2010. “La Situación de la Educación para la Paz en México en la Actualidad." Espacios Públicos, 13 (27): 149-164. http://www.redalyc.org/articulo. oa?id=67613199010.

Ahsan, Zayadul, and Banavar Pavitra. 2011. "Who are the Militants?" In Political Islam and Governance in Bangladesh, edited by Ali Riaz, and C. Christine Fair, 71-90. New York: Routledge.

Akar, Bassel. 2016. “Dialogic Pedagogies in Educational Settings for Active Citizenship, Social Cohesion and Peacebuilding in Lebanon." Education, Citizenship and Social Justice 11 (1): 44-62. doi:10.1177/1746197915626081.

Alam, Safayet. 2011. "Notions of Citizenship in Bangladesh Secondary Curriculum: The Interface between Policy, Perception, and Practice." MEd diss., University of Canterbury.

Alam, Safayet. 2012. "Neoliberalism and Citizenship in the Bangladesh Secondary School Curriculum." Critical Literacy: Theories and Practices 6 (2): 16-30. http://criticalliteracy.freehostia. com/index.php?journal=criticalliteracy\&page=article\&op=viewArticle\&path\%5B\%5D=122.

Anne Tupper, Jennifer. 2014. "The Possibilities for Reconciliation Through Difficult Dialogues: Treaty Education as Peacebuilding." Curriculum Inquiry 44 (4): 469-488.

Avery, Patricia, Sara L. Levy, and Annette M. M. Simmons. 2013. “Deliberating Controversial Public Issues As Part of Civic Education." The Social Studies 104: 105-114. doi:10.1080/00377996.2 012.691571.

Bajaj, Monisha. 2016. "In the Gaze of Gandhi: Peace Education in Contemporary India." In Peace Education: International Perspectives, edited by Monisha Bajaj and Maria Hantzopoulos, 107122. London: Bloomsbury Academic.

Bajaj, Monisha, and Cheila Acosta. 2009. "The Emergence of Human Rights Education Amidst Ethnic Conflict in the Dominican Republic." In Peace Education in Conflict and Post-Conflict Societies, edited by Claire McGlynn, Michalinos Zembylas, Zvi Bekerman, and Tony Gallagher, 43-57. New York: Palgrave MacMillan.

Bangladesh, National Curriculum and Textbook Board. 2012a. National Curriculum: Bangladesh and Global Studies, Language and Culture of Small Ethnic Groups Grades 6-10; History of Bangladesh and World Civilization, Geography and Environment, Civics and Citizenship, Economic 
Grades 9-10. http://www.nctb.gov.bd/document/national_curriculum_2012/5Humanities. pdf.

Bangladesh, National Curriculum and Textbook Board. 2012b. National Curriculum for Primary School:Bangladesh and Global Studies. http://www.nctb.gov.bd/index.php/curriculum-wing/ secondary/.

Bar-Tal, Daniel, Y. Yigal Rosen, and Rafi Nets-Zehngut. 2010. “Peace Education in Societies Involved in Intractable Conflict: Goals, Conditions, and Directions." In Handbook on Peace Education, edited by Gavriel Salomon and Edward Cairns, 21-43. NY: Psychology Press/Taylor \& Francis.

Barton, Keith C. 2015. “Young Adolescents' Positioning of Human Rights: Findings from Colombia, Northern Ireland, Republic of Ireland and the United States." Research in Comparative and International Education 10 (1): 48-70. doi:10.1177/1745499914567819.

Barton, Keith C., and Linda S. Levstik. 2008. "History." In The SAGE Handbook of Education for Citizenship and Democracy, edited by James Arthur, Ian Davies, and Carole Hahn, 355-366. London: Sage. doi:10.4135/9781849200486.

Barton, Keith C., and Alan W. McCully. 2012. "Trying to 'See Things Differently': Northern Ireland Students' Struggle to Understand Alternative Historical Perspectives." Theory \& Research in Social Education 40 (4): 371-408. doi:10.1080/00933104.2012.710928.

Bartusevičius, Henrikas. 2014. "The Inequality-Conflict Nexus Re-examined: Income, Education and Popular Rebellions." Journal of Peace Research 51 (1): 35-50.

Bekerman, Zvi, and Michalinos Zembylas. 2012. Teaching Contested Narratives: Identity, Memory, and Reconciliation in Peace Education and Beyond. Cambridge: Cambridge University Press.

Bellino, Michelle J. 2014. "Whose Past, Whose Present?" In (Re)Constructing Memory: School Textbooks and the Imagination of the Nation, edited by James. H. Williams, 131-151. Rotterdam: Sense. doi:10.1007/978-94-6209-656-1_7.

Bellino, Michelle J. 2015a. "So That We Do Not Fall Again: History Education and Citizenship in "Postwar" Guatemala." Comparative Education Review 60 (1): 58-79. doi:10.1086/684361.

Bellino, Michelle J. 2015b. “Civic Engagement in Extreme Times: The Remaking of Justice Among Guatemala's 'postwar' Generation." Education, Citizenship and Social Justice 10 (2): 118-132. doi:10.1177/1746197915583937.

Bermúdez, Ángela. 2015. "Four Tools for Critical Inquiry in History, Social Studies, and Civic Education." Revista de Estudios Sociales No.35 52 (52): 102-118. doi:10.7440/res52.2015.07.

Bickmore, Kathy. 2008. "Social Studies for Social Justice: Learning/ navigating Power and Conflict." In Handbook of Research in Social Studies, edited by Linda Levstik and Cynthia Tyson, 155-171. Mahwah, NJ: Lawrence Erlbaum.

Bickmore, Kathy. 2014a. "Citizenship Education in Canada: 'Democratic' Engagement with Differences, Conflicts and Equity Issues?" Citizenship Teaching and Learning 9 (3): 257-278. doi:10.1386/ctl.9.3.257_1.

Bickmore, Kathy. 2014b. "Peacebuilding Dialogue Pedagogies in Canadian Classrooms." Curriculum Inquiry 44 (4): 553-582. doi:10.1111/curi.12056.

Bickmore, Kathy. 2015a. "Incorporating Peace-Building Citizenship Dialogue in Classroom Curricula: Contrasting Cases of Canadian Teacher Development." In Building Democracy through Education on Diversity, edited by Suzanne Majhanovich and Régis Malet, 17-39. Rotterdam: Sense.

Bickmore, Kathy. 2015b. "Keeping, Making, and Building Peace in School."In Social Studies Today: Research and Practice, edited by Walter C. Parker, 238-245. NY: Routledge.

Bickmore, Kathy. 2017. "Conflict, Peace-building, and Education: Rethinking Pedagogies in Divided Societies, Latin America, and around the World." In Comparative and International Education: Issues for Teachers. 2nd expanded ed., edited by Kathy Bickmore, Ruth Hayhoe, Caroline Manion, Karen Mundy, and Robyn Read, 268-299. Toronto: Canadian Scholars Press. 
Bickmore, Kathy, Yomna Awad, and Angelica Radjenovic. 2017.“'Voices of Canadian and Mexican Youth Surrounded by Violence: Learning Experiences for Peace-building Citizenship." Research in Comparative and International Education 12 (1), 26-45.

Byrom, Jamie, and Karen Riley. 2007."Identity-shakers: Cultural encounters and the development of pupils' multiple identities." Teaching History (127), 22-29.

Camargo, Diego. 2016. "La Cátedra de Paz, una Construcción entre Estudiantes y Maestros." Compartir Palabra Maestra. http://compartirpalabramaestra.org/blog/la-catedra-de-paz-unaconstruccion-entre-estudiantes-y-maestros.

Chareka, Ottilia, and Alan Sears. 2006. “Civic Duty: Young People's Conceptions of Voting as a Means of Political Participation." Canadian Journal of Education 29 (2): 521-540. go.galegroup.

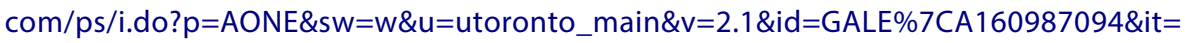
r\&asid=52734b2743eafc27196aa9fd171bf2f3.

Charmaz, Kathy. 2000. "Grounded Theory: Objectivist and Constructivist Methods." In Handbook of Qualitative Research, edited by Norman K. Denzin and Yvonna S. Lincoln, 509-535. Thousand Oaks, CA: Sage.

Colombia, Ministerio Nacional de Educación. 2006a. "Estándares Básicos De Competencias En Ciencias Sociales Y Ciencias Naturales." In Estándares básicos de competencias en Lenguaje, matemáticas, ciencias y ciudadanas. Guía sobre lo que los estudiantes deben saber y hacer con lo que aprenden, 96-147. Bogotá: Ministerio de Educación Nacional.

Colombia, Ministerio Nacional de Educación. 2006b. “Estándares Básicos De Competencias Ciudadanas." In Estándares Básicos de Competencias en Lenguaje, Matemáticas, Ciencias y educación ciudadana. Guía sobre lo que los estudiantes deben saber y saber hacer con lo que aprenden. Bogotá: Ministerio de Educación Nacional.

Davies, Lynn. 2005. "Teaching about Conflict through Citizenship Education." International Journal of Citizenship and Teacher Education 1 (2): 17-34. http://www.dphu.org/uploads/ attachements/books/books_2297_0.pdf.

Davies, Lynn. 2011. "Can Education Interrupt Fragility? Toward the Resilient Citizen and the Adaptable State." In Educating Children in Conflict Zones: Research, Policy and Practice for Systemic Change - A Tribute to Jackie Kirk, edited by Karen Mundy and Sarah Dryden-Peterson, 33-48. New York: Teachers College Press.

Davies, Lynn. 2014. "Interrupting Extremism by Creating Educative Turbulence." Curriculum Inquiry 44 (4): 450-468. doi:10.1111/curi.12061.

De la hoz, Germán. 2013. Comportamiento del homicidio, Colombia. Bogotá: Medicina Legal.

Evans, Ronald W., Patricia G. Avery, and Patricia Velde Pederson. 2000. "Taboo Topics: Cultural Restraint on Teaching Social Issues." The Clearing House: A Journal of Educational Strategies, Issues and Ideas 73 (5): 295-302.

Fanon, Frantz. 2004. The Wretched of the Earth. Translated by Richard Philcox. New York: Grove Press.

Fine-Meyer, Rose. 2013. "Teaching War in the History Classroom: Challenging Dominant Narratives." Antistasis 3 (1): 1-4. https://journals.lib.unb.ca/index.php/antistasis/article/ view/20146/23242.

Foucault, Michel. 2011. The Government of Self and Others: Lectures at the College de France 19821983. Basingstoke: Palgrave Macmillan. ISBN 9781403986672.

Freire, Paulo. 1970. Pedagogy of the Oppressed. New York: Continuum.

Funk, Nathan C., and Abdul Aziz Said. 2004. "Islam and the West: Narratives of Conflict and Conflict Transformation." International Journal of Peace Studies 9 (1): 1-28. http://www.jstor. org/stable/41852908.

Gagne, David. 2015. InSight Crime's 2015 Latin America Homicide Round-up. http://www. insightcrime.org/news-analysis/insight-crime-homicide-round-up-2015-latin-americacaribbean. 
Galtung, Johan. 1996. Peace by Peaceful Means: Peace and Conflict, Development and Civilization. London: Sage.

Ghosh, Shreya. 2012. "Activating Citizenship: The Nation's Use of Education to Create Notions of Identity and Citizenship in South Asia." International Journal of Progressive Education 8 (3): 129-139. http://inased.org/v8n3/ijpev8n3.pdf.

Gill, Scherto, and Ulrike Niens. 2014. "Education as Humanisation: A Theoretical Review on the Role of Dialogic Pedagogy in Peacebuilding Education." Compare: A Journal of Comparative and International Education 44 (1): 10-31. doi:10.1080/03057925.2013.859879.

Gohel, Sajjan M. 2014. "Bangladesh: An Emerging Centre for Terrorism in Asia." Perspectives on Terrorism 8 (3): 84-91. http://www.terrorismanalysts.com/pt/index.php/pot/article/view/348/ html.

Griffin, Shayla R., Mikel Brown, and warren, naomi m. 2012. “Critical Education in High Schools: The Promise and Challenges of Intergroup Dialogue." Equity \& Excellence in Education 45 (1): 159-180. doi:10.1080/10665684.2012.641868.

Guevara, G., and F. Tirado. 2006. “Conocimientos cívicos en Mexico: Un estudio comparativo internacional." Revista Mexicana de Investigación Educativa (Consejo Mexicano de Investigación Educativa) 11 (30): 995-1018.

Gurin-Sands, Chloé, Patricia Gurin, Biren A. Nagda, and Shardae Osuna. 2012. "Fostering a Commitment to Social Action: How Talking, Thinking, and Feeling Make a Difference in Intergroup Dialogue." Equity \& Excellence in Education 45 (1): 60-79. doi:10.1080/10665684 .2012.643699.

Harber, Clive, and Noriko Sakade. 2009. "Schooling for Violence and Peace: How Does Peace Education Differ from 'normal' Schooling?" Journal of Peace Education 6 (2): 171-187. doi:10.1080/17400200903086599.

Helmsing, Mark. 2014. "Virtuous Subjects: A Critical Analysis of the Affective Substance of Social Studies Education." Theory \& Research in Social Education 42 (1): 127-140. doi:10.1080/0093 3104.2013.842530.

Hess, Diana, and Patricia G. Avery. 2008. "Discussion of Controversial Issues as a Form and Goal of Democratic Education." In The SAGE Handbook of Education for Citizenship and Democracy, edited by James Arthur, lan Davies and Carole Hahn, 506-518. Los Angeles, CA: Sage.

Horner, Lindsey, Laila Kadiwal, Yusuf Sayed, Angeline Barrett, Naureen Durrani, and Mario Novelli. 2015. Literature Review: The Role of Teachers in Peacebuilding. Amsterdam: Research Consortium on Education and Peacebuilding, UNICEF \& Learning for Peace.

Hughes, A., and Sears, A. 2008. "The Struggle for Citizenship Education in Canada: the Centre Cannot Hold."In Sage Handbook of Education for Citizenship and Democracy, edited by J. Arthur, I. Davies, and C. Hahn, 124-138. London: Sage Publications.

IEP (Institute for Economics and Peace). 2016. Global Peace Index 2016: Ten Years of Measuring Peace. Accessed from Sydney, New York, Brussels and México City: www.economicsandpeace. org

Islam, Md. Shamsul. 2011. "Political Violence in Bangladesh." In Political Islam and Governance in Bangladesh, edited by Ali Riaz and C. Christine Fair, 27-45. New York: Routledge.

Islam, Md. Hafizul. 2014. "Building Peace in Bangladesh: The Role of Peace Education." M.Phil. diss., University of Dhaka.

Jansen, Jonathan. 2009.“Big Change Question: can and Should School Change in the Developing World be Guided by Research from the Developed World?" Journal of Educational Change 10 (2-3): 239-243. doi:10.1007/s10833-009-9113-2.

Jaramillo, Rosario, and José A. Mesa. 2009. "Citizenship Education as a Response to Colombia's Social and Political Context." Journal of Moral Education 38 (4): 467-487. doi:10.1080/03057240903321931. 
Jenkins, Kathy, and Bertram Jenkins. 2010. "Cooperative Learning: A Dialogic Approach to Constructing a Locally Relevant Peace Education Programme for Bougainville." Journal of Peace Education 7 (2): 185-203. doi:10.1080/17400201.2010.502371.

Justino, Patricia. 2016. "Supply and Demand Restrictions to Education in Conflict-affected Countries: New Research and Future Agendas." International Journal of Educational Development 47: 76-85.

Kaderi, Ahmed Salehin. 2014. "Political History, Political Violence: Peacebuilding Citizenship interventions." In Working with, Against and Despite Global 'Best Practices': Educational Conversations around the Globe, edited by Sarfaroz Niyozov and Paul Tarc, 75-81. Toronto: Ontario Institute for Studies in Education, University of Toronto. https://www.oise.utoronto. ca/cidec/UserFiles/File/Website/Compendium_GBP_Final_Jan_2016.pdf.

Kassimir, Ronald, and Constance Flanagan. 2010. "Youth Civic Engagement in the Developing World: Challenges and Opportunities." In Handbook of Research on Civic Engagement in Youth, edited by Lonnie R. Sherrod, Judith Torney-Purta and Constance A. Flanagan, 91-113. Hoboken, NJ: Wiley.

Kennelly, Jacqueline, and Jo-Anne Dillabough. 2008. "Young People Mobilizing the Language of Citizenship: Struggles for Classification and New Meaning in an Uncertain World." British Journal of Sociology of Education 29 (5): 493-508. doi:10.1080/01425690802263643.

Kennelly, Jacqueline, and Kristina R. Llewellyn. 2011. “Educating for Active Compliance: Discursive Constructions in Citizenship Education." Citizenship Studies 15 (6-7): 897-914. doi:10.1080/ 13621025.2011.600103.

King, John T. 2009. “Teaching and Learning about Controversial Issues: Lessons from Northern Ireland." Theory and Research in Social Education 37 (2): 215-246. doi:10.1080/00933104.200 9.10473395.

Lall, Marie. 2008."Educate to Hate:The Use of Education in the Creation of Antagonistic National Identities in India and Pakistan." Compare: A Journal of Comparative and International Education 38 (1): 103-119. doi:10.1080/03057920701467834.

Lauritzen, Solvor Mjoberg. 2016. "Building Peace through Education in a Post-conflict Environment: A Case Study Exploring Perceptions of Best Practices." International Journal of Educational Development 51: 77-83. doi:10.1016/j.ijedudev.2016.09.001.

Lecamwasam, Nupinika O. 2015. “'United we stand, divided we fall': A Case Study of Sri Lankan Youth in Citizenship Development." International Journal of Adolescence and Youth 20 (4): 442-456. doi:10.1080/02673843.2015.1020819.

Lederach, John Paul. 1995. Preparing for Peace: Conflict Transformation Across Cultures. Syracuse: Syracuse University Press.

Lederach, John Paul. 2003. The Little Book of Conflict Transformation. Intercourse, PA: Good Books. Levy, Sara A. 2014. "Heritage, History, and Identity." Teachers College Record 116 (6): 1-34. http:// www.tcrecord.org/library/abstract.asp?contentid=17467.

Llewellyn, Kristina, and Joel Westheimer. 2009. "Beyond Facts and Acts: the Implications of 'Ordinary Politics' for Youth Political Engagement." Citizenship Teaching and Learning 5 (2): 50-61. http://democraticdialogue.com/DDpdfs/BeyondFactsActs.pdf.

Lopes Cardozo, Mieke, Sean Higging, Elizabeth Maber, Cyril O. Brandt, Nebil Kusmallah, and Marielle Le Mat. 2015. Literature Review: Youth Agency, Peacebuilding and Education. Research Consortium on Education and Peacebuilding, University of Amsterdam. https://pure.uva.nl/ ws/files/2687633/166643_490433.pdf.

Lovat, Terence, and Robert Crotty. 2015. Reconcilling Islam, Christianity, and Judaism: Islam's Special Role in Restoring Convivencia. New York: Springer.

Macdonald, Geoffrey. 2016. Preventing Violent Extremism through Inclusive Politics in Bangladesh. https://www.usip.org/publications/2016/01/preventing-violent-extremism-throughinclusive-politics-bangladesh. 
Magendzo, Abraham, and María Isabel Toledo. 2009.“Moral Dilemmas in Teaching Recent History Related to the Violation of Human Rights in Chile." Journal of Moral Education 38 (4): 445-465. doi:10.1080/03057240903321923.

McCully, A. 2012. "History Teaching, Conflict and the Legacy of the Past." Education, Citizenship and Social Justice 7 (2): 145-159. doi:10.1177/1746197912440854.

México, Secretaría de Educación Pública. 2011a. “Historia." In Programas de Estudio 2011. Guía para el Maestro. Educación Básica Primaria y Secundaria. Quinto y Sexto Grados de Primaria y Segundo y Tercero de Secundaria.

México, Secretaría de Educación Pública. 2011b. "Formación cívica y ética." In Programas de Estudio 2011. Guía para el Maestro. Educación Básica Primaria y Secundaria. Quinto y Sexto Grados de Primaria y Segundo y Tercero de Secundaria.

México, Secretaría de Educación Pública. 2011c. "Geografía." In Programas de Estudio 2011. Guía para el Maestro. Educación Básica Primaria y Secundaria. Quinto y Sexto Grados de Primaria y Primero de Secundaria.

México, Secretaría de Educación Pública. 2011d. “Asignatura Estatal. Formación Ciudadana para los adolescentes de Guanajuato." In Programa de Estudio 2011. Educación Básica Secundaria.

Nieto, Diego, and Kathy Bickmore. 2017. "Citizenship and Convivencia Education in Contexts of Violence: Transnational challenges to peacebuilding education in Mexican schools." Revista Española de Educación Comparada (28): 109-134. doi:10.5944/reec.28.2016.17087.

Norwegian Refugee Council. 2015. Global Overview 2015. People Internally Displaced by Conflict and Violence. Geneva: Norwegian Refugee Council. http://www.internal-displacement.org/ publications/2015/global-overview-2015-people-internally-displaced-by-conflict-andviolence.

van Ommering, Erik. 2015. "Formal History Education in Lebanon: Crossroads of Past Conflicts and Prospects for Peace." International Journal of Educational Development 41: 200-207. doi:10.1016/j.ijedudev.2014.06.009.

Patterson, Nancy. 2010. "What's Stopping You? Classroom Censorship for Better or Worse." Social Education 74 (6): 326-331. http://www.socialstudies.org/publications/socialeducation/ november-december2010/whats_stopping_you_classroom_censorship_for_better_or_ worse.

Paulson, Julia. 2015. "'Whether and how?'History Education about Recent and Ongoing Conflict: A Review of Research." Journal on Education in Emergencies 1 (1): 14-47.

Province of Ontario. 2013a. The Ontario Curriculum Grades 9 \& 10: Canadian and World Studies: Geography, History, Civics (Politics). http://www.edu.gov.on.ca/eng/curriculum/secondary/ canworld910curr2013.pdf.

Province of Ontario. 2013b. The Ontario Curriculum: Social Studies Grades 1-6, History Grades 7\&8, Geography Grades 7\&8. https://www.edu.gov.on.ca/eng/curriculum/elementary/ sshg18curr2013.pdf.

Quaynor, Laura J. 2011. “Citizenship Education in Post-conflict Contexts: A Review of the Literature." Education, Citizenship and Social Justice 7 (1): 33-57. doi:10.1177/1746197911432593.

Reimers, Farnando, and Sergio Cardenas. 2010. "Youth Civic Engagement in Mexico." In Handbook of Research on Civic Engagement in Youth, edited by Lonnie R. Sherrod, Judith Torney-Purta, and Constance A. Flanagan, 139-160. Hoboken, NJ: Wiley.

Riaz, Ali, and Kh. Ali Ar Raji. 2011. "Who are Islamists?" In Political Islam and governance in Bangladesh, edited by Ali Riaz and C. Christine Fair, 46-70. New York: Routledge.

Ross, Marc Howard. 2007. Cultural Contestation in Ethnic Conflict. Cambridge: Cambridge University Press.

Rubin, Beth. 2016. “They Don't Tell It: Indigenous Social Studies Teachers Transforming Curricula in Post-conflict Guatemala." Journal of International Social Studies 6 (1): 114-127. 
Rueda, María Helena. 2008. “Nación y Narración de la Violencia en Colombia (De la Historia a la Sociología)." Revista lberoamericana 74 (223): 345-359.

Ruiz, Alexander, and Enrique Chaux. 2005. La Formación de Competencias Ciudadanas. 1st ed. Bogotá: Ascofade.

Russell, Susan Garnett, and Dijana Tiplic. 2014. "Rights-based Education and Conflict: A Crossnational Study of Rights Discourse in Textbooks." Compare: A Journal of Comparative and International Education 44 (3): 314-334. doi:10.1080/03057925.2013.765288.

Schulz, Wolfram, John Ainley, Julian Fraillon, David Kerr, and Bruno Losito. 2010. ICCS 2009 International report: Civic knowledge, Attitudes, and Engagement among Lower-secondary School Students in 38 Countries. Amsterdam: International Association for the Evaluation of Educational Achievement (IEA). http://files.eric.ed.gov/fulltext/ED520018.pdf.

Schulz, Wolfram, John Ainley, Tom Friedman, and Petra Lietz. 2011. ICCS 2009 Latin American Report: Civic Knowledge and Attitudes Among Lower-secondary Students in six Latin American Countries. Amsterdam. http://www.iea.nl/fileadmin/user_upload/Publications/Electronic_ versions/ICCS_2009_Latin_American_Report.pdf.

Schuster, Sven. 2009. "Las políticas de la historia en Colombia: el primer gobierno del Frente Nacional y el "problema" de La Violencia (1958-1962)." Iberoamericana 9 (36): 9-26.

Sheppard, Maia G. 2010. “Creating a Caring Classroom in which to Teach Difficult Histories." The History Teacher 43 (3): 411-426.

Sheppard, Maia, Doran Katz, and Tanetha Grosland. 2015. "Conceptualizing Emotions in Social Studies Education." Theory \& Research in Social Education 43 (2): 147-178. doi:10.1080/0093 3104.2015.1034391.

Shuayb, Maha. 2012. “Current Model and Approaches to Social Cohesion in Secondary Schools in Lebanon." In Rethinking Education for Social Cohesion: International Case Studies, edited by Maha Shuayb, 137-153. New York: Palgrave Macmillan.

Siddiqi, Dina Mahnaz. 2011."Political Culture in Contemporary Bangladesh: Histories, Ruptures and Contradictions." In Political Islam and governance in Bangladesh, edited by Ali Riaz and C. Christine Fair, 7-26. New York: Routledge.

Sri Lanka Guardian. 2017. "Sri Lanka: 'Reconciliation' will be Included in School Curriculum CBK." Reprinted in Global Campaign for Peace Education. http://www.peace-ed-campaign. org/author/gcpe/.

Steiner-Khamsi, Gita. 2004. "Blazing a Trail for Policy, Theory and Practice." In The Global Politics of Educational Borrowing and Lending, edited by Gita Steiner-Khamsi, 201-220. New York: Teachers College Press.

Tibbitts, Felisa, and Judith Torney-purta. 1999. Citizenship Education in Latin America: Preparing for the Future. Argentina: Education Unit of the Inter-American Development Bank. Human Rights Education Associates (HREA).

Tirado Segura, Felipe, and Gilberto Guevara Niebla. 2006. "Conocimientos cívicos en México: Un estudio comparativo internacional." Revista Mexicana de Investigación Educativa (Consejo Mexicano de Investigación Educativa) 11 (30): 995-1018.

Torney-Purta, J., and J. Amadeo. 2011. “Participatory Niches for Emergent Citizenship in Early Adolescence: An International Perspective." ANNALS of the American Academy of Political and Social Science 633 (1): 180-200.

Toro, Juan José. 2015. “Qué se está enseñando sobre conflicto y paz en los colegios?" http:// pacifista.co/como-se-esta-ensenando-el-conflicto-y-la-paz-en-los-colegios/.

Tupper, Jennifer A., and Michael P. Cappello. 2012."(Re)creating citizenship: Saskatchewan High School Students' Understandings of the 'good' Citizen." Journal of Curriculum Studies 44 (1): 37-59. https://eric.ed.gov/?id=EJ957949.

Ury, William. 2000. The Third Side: Why We Fight and How We can Stop. New York: Penguin Books. 
Vanner, Catherine, Spogmai Akseer, and Thursica Kovinthan. 2017.“'Learning Peace (and Conflict): The Role of Primary Learning Materials in Peacebuilding in Post-war Afghanistan, South Sudan and Sri Lanka." Journal of Peace Education 14 (1): 32-53. doi:10.1080/17400201.2016.1213710.

Williams, James. 2014. (Re)Constructing Memory: School Textbooks and the Imagination of the Nation. Rotterdam: Sense. 